\title{
Soybean-corn succession according to seeding date
}

\author{
Rodrigo Arroyo Garcia(1), Gessí Ceccon ${ }^{(1)}$, \\ Guilherme Afonso da Silva Sutier ${ }^{(2)}$ and Anna Luiza Farias dos Santos ${ }^{(3)}$
}

${ }^{(1)}$ Embrapa Agropecuária Oeste, Rodovia BR 163, Km 253,6, CEP 79804-970 Dourados, MS, Brazil. E-mail: rodrigo.garcia@embrapa.br,
gessi.ceccon@embrapa.br ${ }^{(2)}$ Centro Universitário da Grande Dourados, Rua Balbina de Matos, no 2.121, Jardim Universitário,
CEP 79824-900 Dourados, MS, Brazil. E-mail: guilherme_sutier@hotmail.com ${ }^{(3)}$ Universidade Federal da Grande Dourados, Rodovia
Dourados-Itahum, Km 12, Cidade Universitária, Caixa Postal 533, CEP 79804-970 Dourados, MS, Brazil. E-mail: annaluiza_di@hotmail.com

Abstract - The objective of this work was to evaluate the grain yield of soybean and corn cultivars cropped in succession, in different sowing dates. The experiment was carried out in the municipality of Dourados, in the state of Mato Grosso do Sul, Brazil, during three growing seasons, in the sowing dates: $9 / 15,10 / 1,10 / 15$, and 11/1 for soybean; and 2/1,2/15,3/1, and 3/15 for corn. Although soybean yields are strongly affected by the crop season, sowing between late September and early October results in higher long-term yields. Planting corn in succession in mid-February provides the highest grain yield in the southern region of the state Mato Grosso do Sul; therefore, there is no need for an early soybean sowing in September, in order to ensure corn planting in January. Soybean-corn succession in which soybean is sown in early October and corn in midFebruary results in higher total grain yields and reduces the climatic risk associated with these crops in the region.

Index terms: Glycine max, Zea mays, climatic risk, early sowing, off-season corn, production system.

\section{Sucessão soja/milho em função da época de semeadura}

Resumo - O objetivo deste trabalho foi avaliar a produtividade de cultivares de soja e de milho cultivadas em sucessão, em diferentes épocas de semeadura. O experimento foi realizado em Dourados, MS, durante três safras agrícolas, nas épocas de semeadura: 15/9, 1/10, 15/10 e 1/11 para a soja; e 1/2, 15/2, 1/3 e 15/3 para o milho. Mesmo que as produtividades da soja sejam fortemente afetadas pela época de colheita, a semeadura no final de setembro e no início de outubro proporcionam maiores produtividades em longo prazo. O plantio do milho em sucessão, em meados de fevereiro, proporciona a maior produtividade de grãos na região Sul do Mato Grosso do Sul; portanto, não há necessidade de se adiantar o plantio da soja para setembro com o objetivo de garantir o plantio do milho em janeiro. A sucessão soja-milho em que a soja é semeada no início de outubro e o milho em meados de fevereiro resulta em maiores produtividades totais e reduz o risco climático associado a essas culturas na região.

Termos para indexação: Glycine max, Zea mays, risco climático, semeadura antecipada, milho segunda safra, sistema de produção.

\section{Introduction}

Since the 1990s, soybean-corn succession has become the main agricultural production system in Brazil, particularly in the states of Mato Grosso, Paraná, Goiás, and Mato Grosso do Sul. In several Brazilian municipalities, $100 \%$ of the area planted with summer soybean is succeeded by corn.

Using a variety of cultivars of indeterminate growth type, soybean can be sown from mid-September in this cultivation system. The crop is then harvested in January, and yields are satisfactory. This scheme is very practical when corn succession is planned because the crop can grow in a season with relatively high rainfall and low risk of frost in regions prone to it. In this way, the adverse effects of climate are reduced and the productive potential increases (Braccini et al., 2010; Souza et al., 2015). This scenario differs significantly from that of fixed-growth soybean genotypes, which have longer life cycles and must be sown during the last ten days of October.

Recent data on the production area and secondharvest corn yields clearly indicate the benefits of this cultivation system. In Mato Grosso do Sul, for example, the production area increased from 830,000 to $1,610,000$ ha between 2010 and 2016 (Acompanhamento..., 2016). The average yield rose from 4,000 to $6,000 \mathrm{~kg} \mathrm{ha}^{-1}$ during 
the same time period. As the yield potential increases, growers invest even more in their cultivation system in anticipation of higher yields.

Soybean cultivars of the indeterminate growth type have high yield potential after the onset of flowering and grow to adequate sizes even when they are sown in September (Garcia et al., 2007; Kakiuchi \& Kobata, 2006; Zanon et al., 2015a, 2015b). Some cultivars triple in size after flowering begins. However, this performance is not universally applicable to all cultivars, and yields are relatively low for certain varieties that have been sown early. Therefore, it is essential to know the cultivars available on the market to optimize yield potential (Gadioli et al., 2000; Prado et al., 2001).

Early soybean sowing also facilitates crop protection. Planting between September and October reduces the risk of infestations with Asian soybean rust (Phakopsora pachyrhizi Syd. \& P. Syd.), the soybean looper (Chrysodeixis includens Walker and Rachiplusia nu Guenée), and the neotropical brown stink bug (Euschistus heros Fabricius). Crops that are sown early have the advantage of being planted immediately after the sanitary fallow season.

In view of the aforementioned observations, it is useful to study the benefits of early soybean sowing, taking into consideration the soybean-corn crop system as a whole. In recent years, soybean has been sown early in the season. This practice may have negative effects on crop yield, even when varieties with indeterminate growth are used. Early planting outside the recommended time window for the region may increase the risk that the crop will be subjected to adverse climate conditions. In the southern part of Mato Grosso do Sul, dry sowing (planting before the onset of significant rainfall) has become popular. However, the early succession planting of corn in January has not increased yields because high temperatures at critical stages of crop development frequently occur at this time (Fietz et al. 2013). Soybean and corn cultivars amenable to early sowing must be identified in order to stabilize and increase yields from succession planting.

The objective of this work was to evaluate the grain yield of soybean and corn cultivars cropped in succession, in different sowing dates.

\section{Materials and Methods}

The study was carried out in the municipality of Dourados, in the state of Mato Grosso do Sul, Brazil, in the experimental area of Embrapa Agropecuária Oeste ( $22^{\circ} 13^{\prime} 16^{\prime \prime} \mathrm{S}, 54^{\circ} 48^{\prime} 20^{\prime \prime} \mathrm{W}$, at $430 \mathrm{~m}$ altitude) during the 2013/2014, 2014/2015, and 2015/2016 crop seasons. According to Köppen's classification, the climate of the region is Am, a tropical monsoon (Alvares et al., 2013).

The average monthly rainfall and temperature data are presented in Figure 1. They were collected at the agrometeorological station of Embrapa, located about $300 \mathrm{~m}$ from the experimental area. The soil is classified as a very clayey Latossolo Vermelho distroférrico (Santos et al., 2006), i.e., a Rhodic Ferralsol. Chemical analysis indicated the following: $\mathrm{pH}\left(\mathrm{CaCl}_{2}\right) 5.1 ; 37.5$ $\mathrm{mg} \mathrm{dm}{ }^{-3} \mathrm{P}$ (Melich 1); $29.6 \mathrm{~g} \mathrm{~kg}^{-1}$ organic matter; 5.8 $\mathrm{cmol}_{\mathrm{c}} \mathrm{dm}^{-3} \mathrm{H}+\mathrm{Al} ; 0.63 \mathrm{cmol}_{\mathrm{c}} \mathrm{dm}^{-3} \mathrm{~K} ; 4.0 \mathrm{cmol}_{\mathrm{c}} \mathrm{dm}^{-3}$ $\mathrm{Ca} ; 1.2 \mathrm{cmol}_{\mathrm{c}} \mathrm{dm}^{-3} \mathrm{Mg}$; total exchangeable bases (SB) of $5.83 \mathrm{cmol}_{\mathrm{c}} \mathrm{dm}^{-3}$; cation exchange capacity (CEC) of $11.7 \mathrm{cmol}_{\mathrm{c}} \mathrm{dm}^{-3}$; and base saturation $(\mathrm{V})$ of $50 \%$.

The experimental design was a randomized complete block in split plot, with four replicates. The sowing dates were treated as plots, the summertime soybean cultivars as subplots, and the autumn-wintertime corn cultivars as subsubplots. The areas of the plots, subplots, and subsubplots were 1,000,500, and $250 \mathrm{~m}^{2}$, respectively.

Four soybean planting periods were evaluated: period 1, mid-September; period 2, early October; period 3; mid-October; and period 4, early November. These designations were used for the sowing periods because it was not possible to plant on the same day of the month during the three study years. However, the actual planting dates for the same period over the three years did not vary by more than three days. Irrigation to a depth of $10 \mathrm{~mm}$ was performed when the soil moisture level was inadequate at the start of germination. This practice ensured that the seedlings would emerge on different days in the sowing periods, maintaining the difference among treatments (Table 1).

The BRS 284 and BRS 360 RR soybean (Glycine $\max$ L.) cultivars were used in the first two periods. In the third period, the BRS 388 RR and BRS 1001 IPRO cultivars were planted. All of these are early maturing, have indeterminate growth, and represent the "standard" genotypes planted by growers in September/October in the state of Mato Grosso do Sul. They differ, however, in terms of relative maturity group; BRS 284, BRS 360 RR, BRS 388 RR, and 
BRS 1001 IPRO are classified as 6.3, 6.2, 6.4, and 6.1, respectively.

Four corn (Zea mays L.) sowing periods were also evaluated: period 1, end of January/beginning of February; period 2, mid-February; period 3, beginning
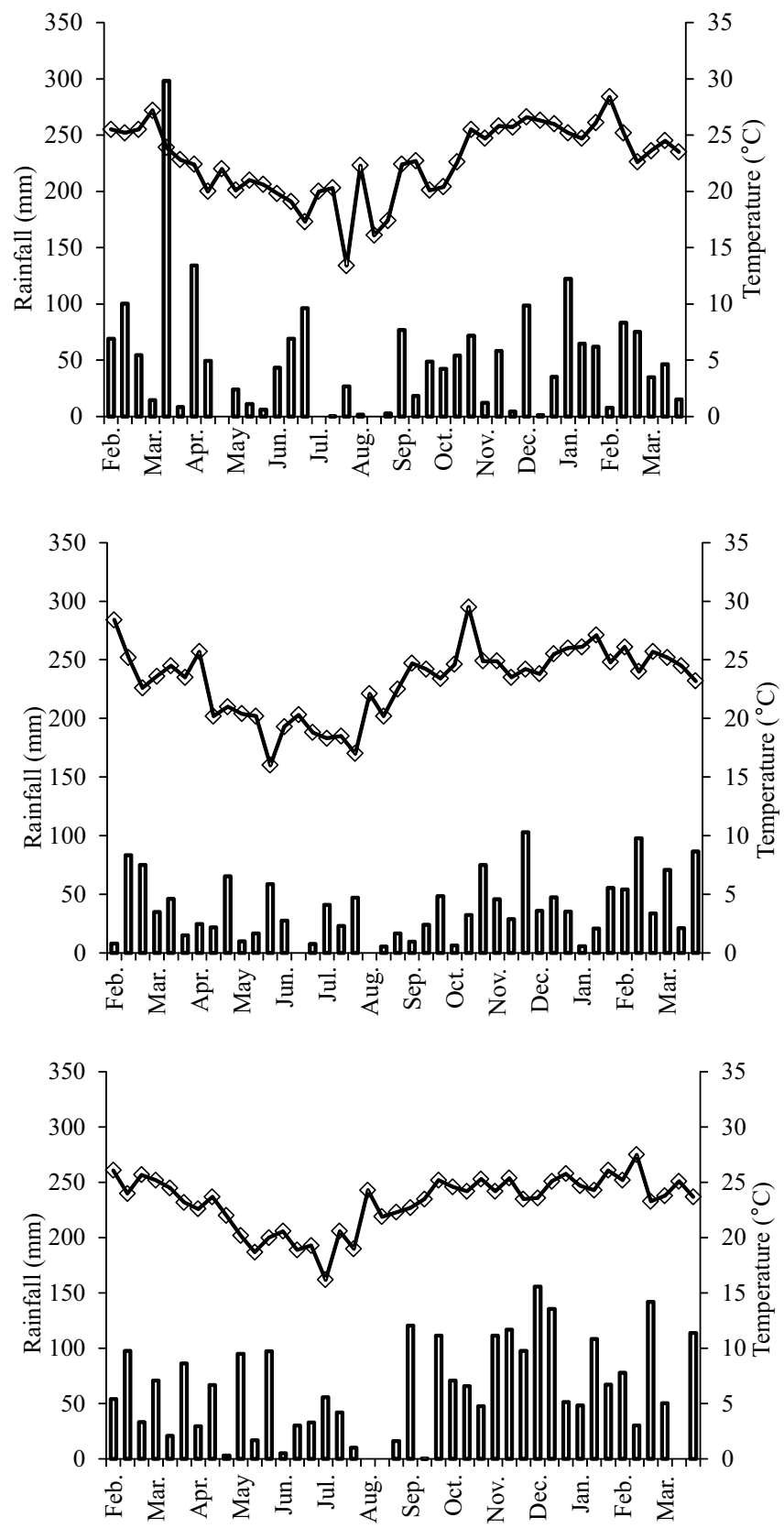

¿Rainfall $\leadsto$ Temperature

Fig. 1. Mean values of temperature and rainfall for ten-day periods during the experiment (February 2013 to March 2016) in the municipality of Dourados, in the state of Mato Grosso do Sul, Brazil. Obtained from the agrometeorological station of Embrapa Agropecuária Oeste. of March; and period 4, mid-March. The BRS 1010 and DKB 390 PRO cultivars were used over three years. They are simple hybrids with early cycles. The fallow intervals between soybean harvest and corn planting differed with each year, but only ranged from one to eight days for the three harvests. These intervals helped minimize the variation at the time of corn planting and were necessary owing to the changes in the soybean cultivar cycles that resulted from the different sowing dates adopted.

The cultivation systems were located in the same place over the three years. Soybean and corn periods 1 were always in the same area. Taken together, these two periods constituted system 1 . The same procedure was applied for periods (and systems) 2, 3, and 4. Both soybean period 1 and corn period 4 occurred outside the agricultural climatic risk zone recommended for the region. These periods accurately and completely represented the regional production systems.

All seeds were directly sown with a PST2 planter (Marchesan Implementos e Máquinas Agrícolas Tatu S.A., Matão, SP, Brazil) at 45-cm intervals. Fertilization was based on soil analyses. Application rates were set to obtain 4-6 $\mathrm{Mg} \mathrm{ha}^{-1}$ corn and 3.5-4.0 $\mathrm{Mg} \mathrm{ha}^{-1}$ soybean. For soybean and corn, fertilizer was applied to the seeding furrow. For corn, another $35 \mathrm{~kg} \mathrm{ha}^{-1} \mathrm{~N}$ was applied as cover. Soybean seed inoculation with $\mathrm{N}$-fixing bacteria and the application of pest control products were performed according to technical recommendations.

Soybean and corn were harvested mechanically from a $10-\mathrm{m}^{2}$ area in each experimental unit. Weights

Table 1. Soybean (Glycine max) and corn (Zea mays) sowing periods in which $10-\mathrm{mm}$ irrigation was required to ensure germination, in the different harvests evaluated in the municipality of Dourados, in the state of Mato Grosso do Sul, Brazil.

\begin{tabular}{lccc}
\hline Sowing dates & \multicolumn{3}{c}{ Harvests } \\
\cline { 2 - 4 } & $2013 / 2014$ & $2014 / 2015$ & $2015 / 2016$ \\
\hline Mid-September & - & Soybean \\
Early October & - & $X$ & $X$ \\
Mid-October & - & $X$ & - \\
Early November & $\mathrm{X}$ & - & - \\
\hline & & Corn & - \\
Beginning of February & $\mathrm{X}$ & $\mathrm{X}$ & - \\
Mid-February & - & - & - \\
Beginning of March & $\mathrm{X}$ & - & $\mathrm{X}$ \\
Mid-March & $\mathrm{X}$ & - & - \\
\hline
\end{tabular}


and moisture content were determined for the samples. Yields were calculated with the water content corrected to $13 \%$. In each agricultural year, the effects of sowing date and cultivar were evaluated. The effect of the seeding date on the average of the three combined soybean and corn harvests was also assessed. The original data were subjected to the analysis of variance (Anova), and the means were compared by the t-test, at $5 \%$ probability. The total yield of the soybean-corn succession was regressed according to the sowing dates. The regression model was selected based on the magnitude of the regression coefficients deemed significant by the F-test, at 5\% probability.

\section{Results and Discussion}

According to the Anova (Table 2), the effects of seeding date, cultivar, and their interaction on crop yields varied with harvest. The effects of the cultivars on the yields within each sowing date were analyzed (Tables 3 and 4), regardless of the interactions between factors. In general, soybean yields were satisfactory except for the 2014/2015 crop season when a severe January drought occurred (Figure 1). The entire 2015/2016 crop season was characterized by above-average monthly rainfall, which resulted in a relatively high incidence of grain rot.

In the 2013/2014 soybean harvest, sowing in early October ensured a relatively high yield, i.e., 3,835 $\mathrm{kg} \mathrm{ha}^{-1}$ with cultivar BRS 284 (Table 3). In contrast, mid-September and early November sowing provided the lowest grain yields. Yield differences between the cultivars were inconsistent and depended on the sowing period. Since the BRS 360 RR cultivar belonged to maturity groups 6.0 and earlier, the crop sown in September had relatively low yield potential even when there was adequate water supply. Braccini et al. (2010) reported that early cultivars sown during

Table 2. Significance of the analysis of variance ${ }^{(1)}$ of the effects of sowing dates and cultivars on soybean (Glycine max) and corn (Zea mays) yields, in the different harvests evaluated in the municipality of Dourados, in the state of Mato Grosso do Sul, Brazil.

\begin{tabular}{lcccc}
\hline Source of variation & \multicolumn{3}{c}{ Harvests } & Mean $^{(2)}$ \\
\cline { 2 - 4 } & $2013 / 2014$ & $2014 / 2015$ & $2015 / 2016$ & \\
\hline \multirow{4}{*}{ Soybean } \\
Sowing date (S) & 0.0000 & 0.0000 & 0.1992 & 0.0021 \\
Cultivar (C) & 0.1423 & 0.0783 & 0.6111 & - \\
SxC & 0.0000 & 0.0000 & 0.0048 & - \\
\hline CV (\%) & 8.08 & 8.92 & 7.57 & 11.09 \\
\hline \multicolumn{5}{c}{ Corn } \\
Sowing date (S) & 0.0000 & 0.1463 & 0.0000 & 0.0001 \\
Cultivar (C) & 0.0666 & 0.0060 & 0.0005 & - \\
SxC & 0.4562 & 0.0004 & 0.2974 & - \\
\hline CV (\%) & 15.09 & 12.49 & 11.74 & 13.10 \\
\hline
\end{tabular}

${ }^{(1)} \mathrm{p}$-value of the F-test. ${ }^{(2)}$ Average of the three soybean and corn harvests, evaluating the main effects of the sowing dates, without considering the interaction effects with the cultivars.

Table 3. Grain yield $\left(\mathrm{kg} \mathrm{ha}^{-1}\right)$ of different soybean (Glycine max) cultivars planted in several dates, in the crop seasons evaluated in in the municipality of Dourados, in the state of Mato Grosso do Sul, Brazil ${ }^{(1)}$.

\begin{tabular}{|c|c|c|c|c|c|}
\hline \multirow[t]{2}{*}{ Cultivar } & \multicolumn{4}{|c|}{ Sowing dates } & \multirow[t]{2}{*}{ Mean } \\
\hline & Mid-September & Early October & Mid-October & Early November & \\
\hline & \multicolumn{5}{|c|}{ Soybean in $2013 / 2014$} \\
\hline BRS 284 & $3,377 \mathrm{Ba}$ & $3,835 \mathrm{Aa}$ & $3,228 \mathrm{Bb}$ & $2,532 \mathrm{Cb}$ & 3,243 \\
\hline BRS $360 \mathrm{RR}$ & $2,681 \mathrm{Bb}$ & $3,640 \mathrm{Aa}$ & $3,662 \mathrm{Aa}$ & 3,564Aa & 3,386 \\
\hline \multirow[t]{2}{*}{ Mean } & $3,029 \mathrm{C}$ & $3,738 \mathrm{~A}$ & $3,445 \mathrm{~B}$ & $3,048 \mathrm{C}$ & - \\
\hline & \multicolumn{5}{|c|}{ Soybean in $2014 / 2015$} \\
\hline BRS 284 & $3,728 \mathrm{Aa}$ & $2,720 \mathrm{Ba}$ & $1,064 \mathrm{Cb}$ & $2,576 \mathrm{Ba}$ & 2,522 \\
\hline BRS 360 RR & $3,208 \mathrm{Ab}$ & 3,051Aa & $2,096 \mathrm{Ba}$ & $2,336 \mathrm{Ba}$ & 2,673 \\
\hline \multirow[t]{2}{*}{ Mean } & $3,468 \mathrm{~A}$ & $2,886 \mathrm{~B}$ & $1,580 \mathrm{D}$ & $2,456 \mathrm{C}$ & - \\
\hline & \multicolumn{5}{|c|}{ Soybean in $2015 / 2016$} \\
\hline BRS 388RR & $3,217 \mathrm{ABa}$ & $3,568 \mathrm{Aa}$ & $2,995 \mathrm{Bb}$ & $3,324 \mathrm{ABa}$ & 3,276 \\
\hline BRS 1001IPRO & $3,213 \mathrm{ABa}$ & $3,244 \mathrm{ABa}$ & $3,515 \mathrm{Aa}$ & $2,952 \mathrm{Bb}$ & 3,231 \\
\hline \multirow[t]{2}{*}{ Mean } & 3,215 & 3,406 & 3,255 & 3.138 & - \\
\hline & \multicolumn{5}{|c|}{ Mean of three harvests } \\
\hline Mean of cultivars & $3,238 \mathrm{~A}$ & $3,344 \mathrm{~A}$ & $2,760 \mathrm{~B}$ & $2,881 \mathrm{~B}$ & - \\
\hline
\end{tabular}

${ }^{(1)}$ Means followed by equal letters, uppercase in the lines and lowercase in the columns, do not differ by the t-test, at $5 \%$ probability. 
this period are relatively smaller in size and have low yield potential. The practice of sowing early cultivars in this period has increased in order to prepare for the corn crop in succession planting. However, the results of the present study and those of Braccini et al. (2010) indicate the need for caution in adopting this practice.

In the 2014/2015 harvest, mid-September sowing produced higher yields, whereas mid-October planting resulted in lower yields (Table 3) because of water limitation (Figure 1). During the summer (January), plants sown in September were already in the final stages of grain filling, so there were no significant reductions in dry matter accumulation and in grain yield. The BRS 360 RR cultivar was less productive than BRS 284 when sowing was performed in mid-September. These results indicate that the yield potentials of early-maturing genotypes may be compromised under these conditions. However, the BRS 360 RR cultivar, particularly when sown in mid-October, showed relatively greater hardiness in the 2014/2015 harvest. Therefore, cultivar diversification is very important in production systems. The yields of the crops sown in early October were lower than those of the crops sown in the first sowing date but higher than those of the crops sown in midOctober and early November.

In the 2015/2016 harvest, sowing date had no significant effect on soybean yield (Tables 2 and 3). The BRS 388 RR and BRS 1001 IPRO cultivars showed vigorous vegetative growth even when sown early. When the cultivars were evaluated individually (Table 3), the yields of BRS 1001 IPRO were relatively low for early November sowing.

There was no consistent correlation between soybean yield and sowing date over the three years of this experiment. This result underscores the importance of varying sowing periods, since the climatic conditions in the south of Mato Grosso do Sul are irregular. However, the average of the three harvests indicated that soybean planting between mid-September and early October provided higher yields than those obtained for the traditional sowing periods of mid-October to early November (Tables 2 and 3). Fietz et al. (2013) concluded that, in the south of Mato Grosso do Sul, the climatic risk of sowing in the last third of September is the same as that for midOctober as long as the soil has adequate moisture at early planting. Fietz et al. (2013) emphasized that even though early germination affects crop performance, early genotypes are not indicated, since not all of them tolerate September planting.

It is necessary to consider that mid-September soybean planting usually precedes spring rains, so soil conditions may not yet be adequate for sowing. Table 1 shows that $10 \mathrm{~mm}$ of irrigation was required to ensure germination for two of the three first-period soybean crops.

Corn yields were relatively high for the intercrops assessed in 2013, 2014, and 2015 (Table 4). In 2013, the

Table 4. Grain yield ( $\left.\mathrm{kg} \mathrm{ha}^{-1}\right)$ of different corn (Zea mays) cultivars planted in several dates, in the different crop seasons evaluated in the municipality of Dourados, in the state of Mato Grosso do Sul, Brazil ${ }^{(1)}$.

\begin{tabular}{|c|c|c|c|c|c|}
\hline \multirow[t]{2}{*}{ Cultivar } & \multicolumn{4}{|c|}{$\begin{array}{l}\text { Sowing dates } \\
\end{array}$} & \multirow[t]{2}{*}{ Mean } \\
\hline & Beginning of February & Mid-February & Beginning of March & Mid-March & \\
\hline & \multicolumn{5}{|c|}{ Corn in 2013} \\
\hline BRS 1010 & 8,046 & 9,120 & 7,645 & 4,810 & 7,405 \\
\hline DKB 390 & 8,981 & 10,574 & 7,305 & 5,962 & 8,205 \\
\hline \multirow[t]{2}{*}{ Mean } & $8,513 \mathrm{~B}$ & $9,847 \mathrm{~A}$ & $7,475 \mathrm{~B}$ & $5,386 \mathrm{C}$ & - \\
\hline & \multicolumn{5}{|c|}{ Corn in 2014} \\
\hline BRS 1010 & $5,302 \mathrm{Bb}$ & $6,669 \mathrm{Aa}$ & $5,147 \mathrm{Bb}$ & $6,041 \mathrm{ABa}$ & $5,789 \mathrm{~b}$ \\
\hline DKB 390 & $8,141 \mathrm{Aa}$ & $5,761 \mathrm{Ba}$ & $6,475 \mathrm{Ba}$ & $6,088 \mathrm{Ba}$ & $6,616 \mathrm{a}$ \\
\hline \multirow[t]{2}{*}{ Mean } & 6,721 & 6,215 & 5,811 & 6,064 & - \\
\hline & \multicolumn{5}{|c|}{ Corn in 2015} \\
\hline BRS 1010 & 5,565 & 8,025 & 5,877 & 5,494 & $6,240 \mathrm{~b}$ \\
\hline DKB 390 & 7,157 & 8,693 & 7,658 & 5,995 & $7,376 \mathrm{a}$ \\
\hline \multirow[t]{2}{*}{ Mean } & $6,361 \mathrm{BC}$ & $8,359 \mathrm{~A}$ & $6,767 \mathrm{~B}$ & $5,744 \mathrm{C}$ & - \\
\hline & \multicolumn{5}{|c|}{ Mean of three harvests } \\
\hline Mean of cultivars & $7,199 \mathrm{~B}$ & $8,141 \mathrm{~A}$ & $6,685 \mathrm{BC}$ & $5,732 \mathrm{C}$ & - \\
\hline
\end{tabular}

(1)Means followed by equal letters, uppercase in the lines and lowercase in the columns, do not differ by the t-test, at $5 \%$ probability. 
DKB 390 hybrid sown in mid-February yielded 10,574 $\mathrm{kg} \mathrm{ha}^{-1}$. Therefore, the second corn crop has a high yield potential in the southern region of Mato Grosso do Sul (Acompanhamento, 2016). Unlike soybean, corn yields for the same sowing dates were relatively consistent over the three harvests. DKB 390 often presented higher yields than the BRS 1010 cultivar in each agricultural year.

Yields were relatively high for the three intercrops resulting from the late-January and early-February sowings. For the 2013 harvest, the average yield was
8,513 $\mathrm{kg} \mathrm{ha}^{-1}$ (Table 4). In later planting (March), however, grain yield was significantly reduced. By mid-March, average yields were $<6,000 \mathrm{~kg} \mathrm{ha}^{-1}$. This sowing period is not indicated for this agricultural zone owing to the climatic risk there at that time. In addition to reducing grain yield, late sowing increases the risk of frost damage. Therefore, using other crops to improve the production system is an appropriate strategy for this region (Garcia et al., 2013; Lima et al., 2015). Sans \& Guimarães (2008) reported that when sowing is postponed until after mid-February, the negative effects
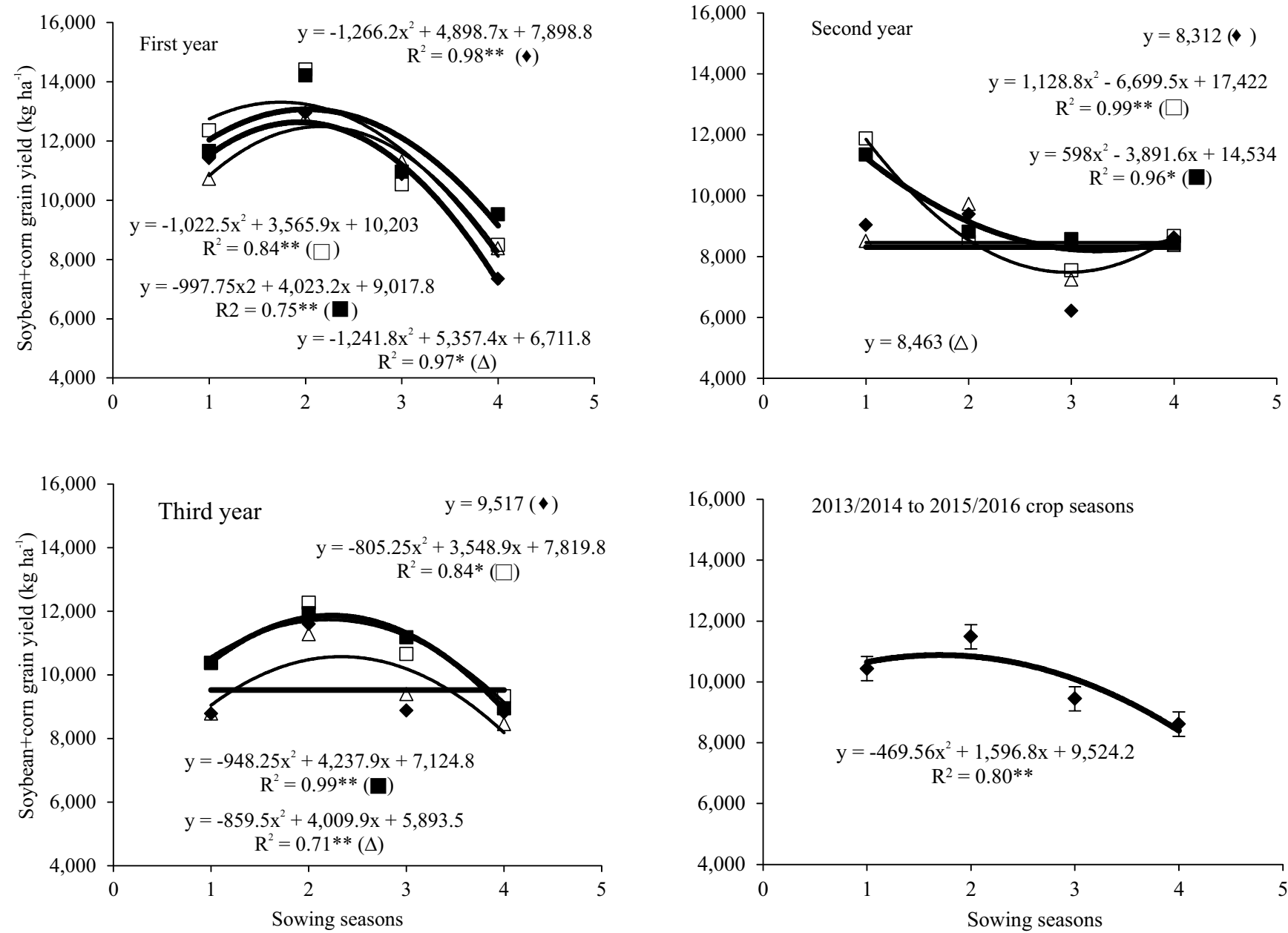

Figure 2. Total yield ( $\mathrm{kg} \mathrm{ha}^{-1}$ ) of the soybean (Glycine max)-corn (Zea mays) successions in 2013/2014 (A), $2014 / 2015$ (B), $2015 / 2016$ (C), and the mean of the three study years (D), according to the different sowing dates and soybean and corn cultivars. First period: soybean sown on September 15 and corn sown on February 1; second period: soybean sown on October 1 and corn sown on February 15; third period: soybean sown on October 15 and corn sown on March 1; and fourth period: soybean sown on November 1 and corn sown on March 15. A and B charts: $\downarrow$ BRS 284 and BRS 1010; $\square$, BRS 284 and DKB 390; $\Delta$, BRS 360 RR, and BRS 1010; and $\mathbf{n}$, BRS 360 RR and DKB 390. C chart: $\star$, BRS 388RR and BRS 1010; $\square$, BRS 388RR and DKB 390; $\Delta$, BRS 1001IPRO and BRS 1010; and $\mathbf{m}$, BRS 1001IPRO and DKB 390.* and **Significant by the F-test, at 5 and 1\% probability, respectively. Least significant difference (LSD) between the seasons for the average of the three harvests: $793 \mathrm{~kg} \mathrm{ha}^{-1}$. 
of precipitation, solar radiation, and temperature levels on corn yields increase. Braccini et al. (2010) conducted a study in the municipality of Maringá, in the state of Paraná, also in Brazil, and observed similar yields for the late January and mid-February sowing periods in the first year of experimentation. In the second year, however, sowing in February provided relatively higher yields. This result aligns with the findings of the present study.

In another experiment carried out in the municipality of Pompeia, in the state of São Paulo, Brazil, Pinotti et al. (2014) found that February sowing provided the highest corn yield, followed by January and March planting. In January, the most limiting factor on yield was the elevated temperature. In March, however, reductions in photoperiod, temperature, and water availability reduced yield. According to Gonçalves et al. (2002), the most preferable sowing periods are those which have both adequate temperature and soil moisture levels. According to Richetti et al. (2015), the break-even point of off-season corn is 82 bags per ha. That is, a minimum yield of $4,920 \mathrm{~kg} \mathrm{ha}^{-1}$ is required to avoid financial loss. The authors suggested that, based on grain yield alone, sowing carried out in and after mid-March is not economically viable.

Four cultivar combinations were evaluated to determine the overall yield of the soybean-corn succession system (Figure 2). According to Table 2, there was a significant interaction effect between cultivar and sowing dates. In the first crop year assessed, soybean/ corn succession yields were independent of the genotypes used (Figure 2 A). The highest yields were obtained in the second soybean sowing period (early October) followed by corn planting in mid-February. Similar results were found for the third crop year (Figure $2 \mathrm{C}$ ). In the second crop year, however, there were significant interactions among the various combinations of soybean and corn cultivars. The highest yields were obtained using the first period sowing (Figure $2 \mathrm{~B}$ ), which had a large positive effect on soybean yield in 2014/2015 (Table 3). These results were reflected in the prices of the grains derived from the soybean-corn succession planting. The average of the three harvests (Figure 2 D) indicates that the total yield of the succession planting was relatively higher for system 2 (soybean planted in early October and corn sown in mid-February). It is important to note, however, that the selection of the system must not be based solely on grain yield analyses; rather, economic considerations should prevail here.

For the crop succession system evaluated here, early sowing results in relatively higher yields. Soybean planting in early October provided more consistent longterm yield gains. The greatest yield potentials for corn were achieved with mid-February planting. September soybean sowing increases cultivation risks and does not provide consistent corn succession yield gains (Table 4). In mid-September, soil moisture content is still relatively low and requires "dry" sowing. Moreover, relatively few soybean cultivars sown in mid-September have high yield potentials.

\section{Conclusions}

1. Although soybean (Glycine max) yields are strongly affected by crop season, sowing between late September and early October results in higher longterm yields.

2. Planting corn (Zea mays) in succession in midFebruary provides the highest grain yield in the southern region of the state Mato Grosso do Sul, Brazil; therefore, there is no need for an early soybean sowing in September to ensure corn planting in January.

3. Soybean-corn succession in which soybean is sown in early October and corn in mid-February results in relatively higher total grain yields and reduces the climatic risk associated with these crops in studied region.

\section{Acknowledgments}

To Coordenação de Aperfeiçoamento de Pessoal de Nível Superior (Capes), for scholarship granted and to Empresa Brasileira de Pesquisa Agropecuária (Embrapa), for financial support.

\section{References}

ACOMPANHAMENTO DA SAFRA BRASILEIRA [DE] GRÃOS: safra 2015/16: nono levantamento, v.3, n.9, jun. 2016. 169p. Available at: <http://www.conab.gov.br/OlalaCMS/uploads/ arquivos/16_06_09_16_49_15_boletim_graos_junho_2016_final.pdf>. Accessed on: June 202016.

ALVARES, C.A.; STAPE, J.L.; SENTELHAS, P.C.; GONÇALVES, J.L. de M.; SPAROVEK, G. Koppen's climate classification map for Brazil. Meteorologische Zeitschrift, v.22, p.711-728, 2013. DOI: 10.1127/0941-2948/2013/0507. 
BRACCINI, A. de L.; STÜLP, M.; ALBRECHT, L.P.; ÁVILA, M.R.; SCAPIM, C.A.; RICC, T.T. Agronomic traits and seed yield produced in the soybean-corn crop in succession cropping. Acta Scientiarum. Agronomy, v.32, p.651-661, 2010. DOI: 10.4025/ actasciagron.v32i4.8064.

FIETZ, C.R.; COMUNELLO, É.; CECCON, G.; FLUMIGNAN, D.L.; SENTELHAS, P.C. Risco climático do consórcio milho com braquiária em Mato Grosso do Sul. In: CECCON, G. (Ed.). Consórcio Milho-Braquiária. Brasília: Embrapa, 2013. p.89112.

GADIOLI, J.L.; DOURADO-NETO, D.; GARCIA Y GARCIA, A.; BASANTA, M. del V. Temperatura do ar, rendimento de grãos de milho e caracterização fenológica associada à soma calórica. Scientia Agricola, v.57, p.377-383, 2000. DOI: 10.1590/S010390162000000300001.

GARCIA, A.; PÍPOLO, A.E.; LOPES, I. de O.N.; PORTUGAL, F.A.F. Instalação da lavoura de soja: época, cultivares, espaçamento e população de plantas. Londrina: Embrapa Soja, 2007. 10p. (Embrapa Soja. Circular técnica, 51).

GARCIA, R.A.; LI, Y.; ROSOLEM, C.A. Soil organic matter and physical attributes affected by crop rotation under no-till. Soil Science Society of American Journal, v.77, p.1724-1731, 2013. DOI: $10.2136 /$ sssaj2012.0310.

GONÇALVES, S.L.; CARAMORI, P.H.; WREGE, M.S.; SHIOGA, P.; GERAGE, A.C. Épocas de semeadura do milho "safrinha", no Estado do Paraná, com menores riscos climáticos. Acta Scientiarum. Agronomy, v.24, p.1287-1290, 2002. DOI: 10.4025/actasciagron.v24i0.2281.

KAKIUCHI, J.; KOBATA, T. The relationship between dry matter increase of seed and shoot during the seed-filling period in three kinds of soybeans with different growth habits subjected to shading and thinning. Plant Production Science, v.9, p.20-26, 2006. DOI: $10.1626 /$ pps.9.20.

LIMA, L.B. de; PETTER, F.A.; LEANDRO, W.M. Desempenho de plantas de cobertura sob níveis de compactação em Latossolo Vermelho de Cerrado. Revista Brasileira de Engenharia Agrícola e Ambiental, v.19, p.1064-1071, 2015. DOI: 10.1590/1807-1929/agriambi.v19n11p1064-1071.

PINOTTI, E.B.; BICUDO, S.J.; GODOY, L.J.G. de; BUENO, C.E.M.S. Características agronômicas de cultivares de milho em função de populações de plantas e épocas de semeadura. Revista Científica Eletrônica de Agronomia, v.25, p.17-33, 2014.

PRADO, E.E. do; HIROMOTO, D.M.; GODINHO, V. de P.C.; UTUMI, M.M.; RAMALHO, A.R. Adaptabilidade e estabilidade de cultivares de soja em cinco épocas de plantio no cerrado de Rondônia. Pesquisa Agropecuária Brasileira, v.36, p.625-635, 2001. DOI: 10.1590/S0100-204X2001000400005.

RICHETTI, A.; FLUMIGNAN, D.L.; ALMEIDA, A.C. dos S. Viabilidade econômica do milho safrinha, sequeiro e irrigado, na Região Sul de Mato Grosso do Sul, para 2016. Dourados: Embrapa Agropecuária Oeste, 2015. 13p. (Embrapa Agropecuária Oeste. Comunicado técnico, 207).

SANS, L.M.A.; GUIMARÃES, D.P. Zoneamento agrícola: riscos climáticos para a cultura do milho. In: CRUZ, J.C.; KARAM, D.; MONTEIRO, M.A.R.; MAGALHÃES, P.C. (Ed.). A cultura do milho. Sete Lagoas: Embrapa Milho e Sorgo, 2008. p.89-97.

SANTOS, H.G. dos; JACOMINE, P.K.T.; ANJOS, L.H.C. dos; OLIVEIRA, V.A. de; OLIVEIRA, J.B. de; COELHO, M.R.; LUMBRERAS, J.F.; CUNHA, T.J.F. (Ed.). Sistema brasileiro de classificação de solos. 2.ed. Rio de Janeiro: Embrapa Solos, 2006. 412 p.

SOUZA, E.J. de; CUNHA, F.F. da; MAGALHÃES, F.F.; SILVA, T.R. da; SANTOS, O.F. dos. Effect of irrigation and nitrogen fertilization on agronomic traits of sweet corn. Pesquisa Agropecuária Tropical, v.45, p.282-290, 2015. DOI: 10.1590/1983-40632015v4533628.

ZANON, A.J.; STRECK, N.A.; RICHTER, G.L.; BECKER, C.C.; ROCHA, T.S.M. da; CERA, J.C.; WINCK, J.E.M.; CARDOSO, A.P.; TAGLIAPIETRA, E.L.; WEBER, P.S. Contribuição das ramificações e a evolução do índice de área foliar em cultivares modernas de soja. Bragantia, v.74, p.279-290, 2015a. DOI: $10.1590 / 1678-4499.0463$.

ZANON, A.J.; WINCK, J.E.M.; STRECK, N.A.; ROCHA, T.S.M. da; CERA, J.C.; RICHTER, G.L.; LAGO, I.; SANTOS, P.M. dos; MACIEL, L. da R.; GUEDES, J.V.C.; MARCHESAN, E. Desenvolvimento de cultivares de soja em função do grupo de maturação e tipo de crescimento em terras altas e terras baixas. Bragantia, v.74, p.400-411, 2015b. DOI: 10.1590/1678-4499.0043.

Received on November 9, 2016 and accepted on June 7, 2017 